\title{
Presence of amastigotes in the central nervous system of hamsters infected with Leishmania sp.
}

\author{
Presença de amastigotas em sistema nervoso central de hamster infectado com Leishmania sp.
}

Elisangela de Oliveira ${ }^{1 *}$; Elisa Teruya Oshiro ${ }^{1}$; Rebeca Vieira Pinto ${ }^{1}$; Bruna Corrêa de Castro $^{1}$; Karla Borges Daniel ${ }^{1}$; Janaina Michelle de Oliveira ${ }^{1}$; Manoel Sebastiāo da Costa Lima Júnior ${ }^{2}$; Euripedes Batista Guimarães ${ }^{3}$; Jesiel Mamedes Silva ${ }^{4}$; Maria Elizabeth Cavalheiros Dorval ${ }^{1}$

\begin{abstract}
${ }^{1}$ Laboratório de Parasitologia, Departamento de Patologia, Centro de Ciências Biológicas e da Saúde, Faculdade de Medicina, Universidade Federal de Mato Grosso do Sul - UFMS

${ }^{2}$ Laboratório de Biologia Molecular e Culturas Celulares, Departamento de Biologia, Centro de Ciências Biológicas e da Saúde, Universidade Federal de Mato Grosso do Sul - UFMS

${ }^{3}$ Laboratório de Anatomia Patológica Veterinária, Departamento de Medicina Veterinária, Faculdade de Medicina Veterinária e Zootecnia, Universidade Federal de Mato Grosso do Sul - UFMS

${ }^{4}$ Laboratório de Histologia, Departamento de Morfofisiologia, Centro de Ciências Biológicas e da Saúde, Universidade Federal de Mato Grosso do Sul - UFMS
\end{abstract}

Received May 19, 2010

Accepted March 16, 2011

\begin{abstract}
Visceral leishmaniasis $(\mathrm{VL}$ ) is a severe chronic disease caused by Leishmania (Leishmania) infantum chagasi. Better knowledge on the effects caused by this disease can help develop adequate clinical management and treatment. Parasitological and immunohistochemical studies were performed golden hamsters Mesocricetus auratus infected with bone marrow from individuals with VL in the State of Mato Grosso do Sul, central-west Brazil. The effects of parasitism in the spleen, liver, kidneys, lungs, heart and brain of the animals were examined. Eighteen hamsters were inoculated intraperitoneally, and six healthy animals were used as negative controls. The animals were kept in the animal house and checked for clinical signs. Specimens of each organ were examined for the presence of amastigotes. Immunohistochemical technique was performed in all brain specimens and organs negative on the direct examination of parasites. Direct examination of amastigotes was positive in the spleen and liver of all infected animals; 33.3\% showed the parasite in the kidneys and lungs, and $16.7 \%$ in the heart. Parasitic forms were seen in $83.3 \%$ (15/18) of the brain examined. Immunohistochemistry confirmed the results of the direct examination, except in two specimens of lung tissue and in the brain specimens. Other studies are needed to further clarify the effect of the parasite in the central nervous system.

Keywords: Visceral leishmaniasis, immunohistochemistry, brain, hamster.
\end{abstract}

\section{Resumo}

A leishmaniose visceral (LV) é uma doença crônica grave, causada pelo parasito Leishmania (Leishmania) infantum chagasi. Esclarecer as alteraçóes provocadas pela doença é fundamental para que se adotem condutas clínicas e de tratamento adequadas. Com o objetivo de analisar a infecção experimental em hamsters da linhagem golden, Mesocricetus auratus, infectados com tecido de medula óssea de pacientes com LV no Estado de Mato Grosso do Sul, foram realizados estudos parasitológicos e de imunomarcação. Foi verificada a distribuição do parasitismo no baço, fígado, rim, pulmão, coraçăo e encéfalo desses animais. Foram utilizados 18 hamsters experimentalmente inoculados via intra-peritoneal, e seis animais sadios como controles negativos. Os animais foram mantidos em biotério de experimentaçáo e observados, em busca de alterações clínicas. Com fragmentos de cada órgão, procedeu-se a confecção de lâminas por aposição para pesquisa de amastigotas. Nos órgáos com resultado negativo na pesquisa direta do parasito, e em todas as amostras de encéfalo, foi realizada a técnica de imunohistoquímica. A pesquisa direta de amastigotas foi positiva no baço e fígado de todos os animais infectados; 33,3\% apresentaram o parasito em rim e pulmão, e 16,7\% no coração. Quando realizada

\footnotetext{
${ }^{*}$ Corresponding author: Elisangela de Oliveira

Laboratório de Parasitologia, Departamento de Patologia,

Centro de Ciências Biológicas e da Saúde, Faculdade de Medicina,

Universidade Federal de Mato Grosso do Sul - UFMS,

CP 549, CEP 79070-900, Campo Grande - MS, Brazil;

e-mail: elisoli@pop.com.br
} 
a pesquisa em encéfalo, formas parasitárias foram observadas em 83,3\% (15/18) dos animais. A imunomarcação confirmou os resultados da pesquisa direta, exceto em duas amostras de tecido pulmonar e nas amostras de encéfalo. Mais estudos são necessários, para esclarecer o real papel do parasito no sistema nervoso central.

Palavras-chave: Leishmaniose visceral, imunohistoquímica, encéfalo, hamster.

\section{Introduction}

Visceral leishmaniasis (VL) is a severe chronic disease of public health concern. VL is endemic in Brazil occurring in 21 states (PENNA, 2008). In the Central-west State of Mato Grosso do Sul, there were 1618 confirmed and reported cases in the period from 2001 to 2008 (MATO GROSSO DO SUL, 2009).

$\mathrm{VL}$ is a systemic disease that infects phagocytic monocytic cells (BRASIL, 2006), and the most affected organs are the spleen, liver (PRAKASH et al., 2006), lymphnodes and bone marrow (MELO, 2004).

The best experimental model to study VL is the golden hamster Mesocricetus auratus because the pathogenesis and clinical manifestations in this animal are similar to those seen in human disease with splenomegaly, pancytopenia, hypergammaglobulinemia and suppression of T-cell proliferation (OLIVEIRA et al., 2004; GOTO; LINDOSO, 2004).

In view of this disease severity and increasing rates of parasitosis, and also taking into consideration the study of the disease in an experimental model that permits the accomplishment of infeasible research in humans, and the fact that the knowledge about the disease is essential for appropriate prophylactic and treatment procedures, this study aimed to assess the effects of VL parasitism in different organs of hamsters Mesocricetus auratus experimentally infected with tissue from bone marrow of patients with VL.

\section{Material and Methods}

Twenty-four 30-day-old Mesocricetus auratus hamsters, Golden strain, both males and females, were used in the study. The animals were provided by the animal house of the Universidade Federal de Mato Grosso do Sul (UFMS). The study was approved by the CEUA/UFMS Research Ethics Committee (protocol no. 125/2006). Bone marrow specimens from 18 patients attended at health care centers institution in the capital city of Campo Grande were used. The material was sent to the UFMS Laboratory of Parasitology for VL diagnosis. Five isolates of the parasite were characterized as Leishmania (Leishmania) infantum chagasi at the UFMS Laboratory of Molecular Biology by polymerase chain reaction (PCR standard) test with RV1/RV2 initiators (LACHAUD et al., 2002; FERROGLIO et al., 2006; SILVA et al., 2008). The remaining specimens are still in process of identification.

Eighteen animals were inoculated $(0.5 \mathrm{~mL})$ intraperitoneally with a bone marrow specimen from each patient. Six healthy hamsters were used as negative controls. The animals were kept in the animal house of the Parasitology Laboratory with animal feed and water ad libitum, and examined for clinical alterations consistent with VL on a weekly basis. Four months post-inoculation, or ith the development of clinical signs such as weight loss, hepatosplenomegaly and ascites, the animals were anesthetized intraperitoneally with $0.70 \mathrm{mg} \cdot \mathrm{kg}^{-1}$ of $10 \%$ sodium pentobarbital solution and euthanized by sectioning their abdominal aorta. Specimens were collected from the brain, heart, lungs, kidneys, liver and spleen. Slides were made after Giemsa staining and examined with the aid of a light microscope at $1.000 \times$ magnification for the presence of amastigotes. Specimens of negative organs by impression technique (15 hearts, 12 kidneys, 12 lungs) and all brain specimens were stored in 10\% formaldehyde and embedded in paraffin for immunohistochemistry.

From the material embedded in paraffin $3 \mu \mathrm{m}$ thick sections were obtained, deposited on silanized slides without paraffin and hydrated in PBS buffer. Antigens were retrieved using a commercial solution (Target Retrieval Solution) and 3\% hydrogen peroxide for blocking endogenous peroxidase. The primary antibodies were sera from dogs naturally infected with VL diluted at $1 / 100$. Biotinylated secondary antibody (LSAB + Sys HRP), streptavidin/ biotin complex and diaminobenzidine liquid chromogen (DAB) $60 \mathrm{mg} \%$ were also used. The slides were counterstained with hematoxylin, and mounted in Enttelan and examined under light microscopy $(1.000 \times)$. It was considered a positive reaction when there was a brown marking consistent with morphological structures of amastigotes. A spleen section of an animal parasitologically positive was used as a positive control. Sections of the spleen, heart, kidneys, lungs and brain of a healthy animal were used as negative controls.

\section{Results}

Of the 18 animals infected, 13 (72.2\%) had splenomegaly, $10(55.5 \%)$ had apparent weight loss and hepatomegaly and ascites were seen in $6(33,3 \%)$ animals. The average time for symptom onset was 3.5 months.

The direct examination of amastigotes was positive in the spleen and liver of all infected animals, 33.3\% had parasites in the kidneys and lungs, and $16.7 \%$ in the heart. When brain specimens were examined, amastigotes were seen in $83.3 \%$ of the animals examined (Figure 1).

Clinical alterations and parasites were not seen in negative controls on direct examination (Figure 2).

Immunohistochemistry markings with an intense background staining were seen in 12 kidney specimens, and also in negative controls, making the analysis of this organ infeasible. In other organs there was no reaction in negative controls.

Immunomarking did not reveal the presence of parasitic forms in the 15 negative heart specimens in the direct examination of parasites, or in the 18 brain specimens. In the lungs, two specimens were positive by immunohistochemistry. 


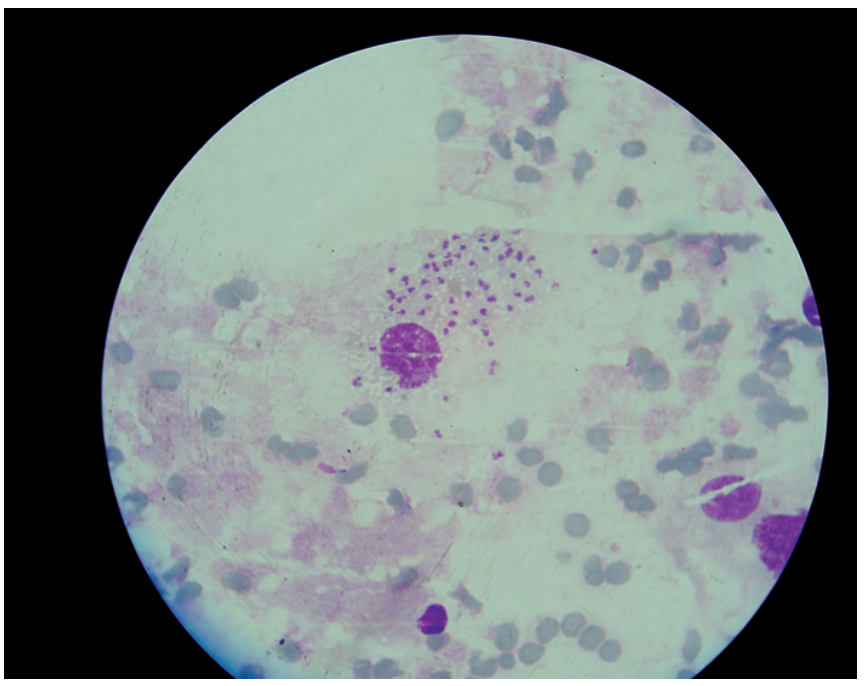

Figure 1. Amastigotes in the brain, organ impression, Giemsa staining (1000× magnification).

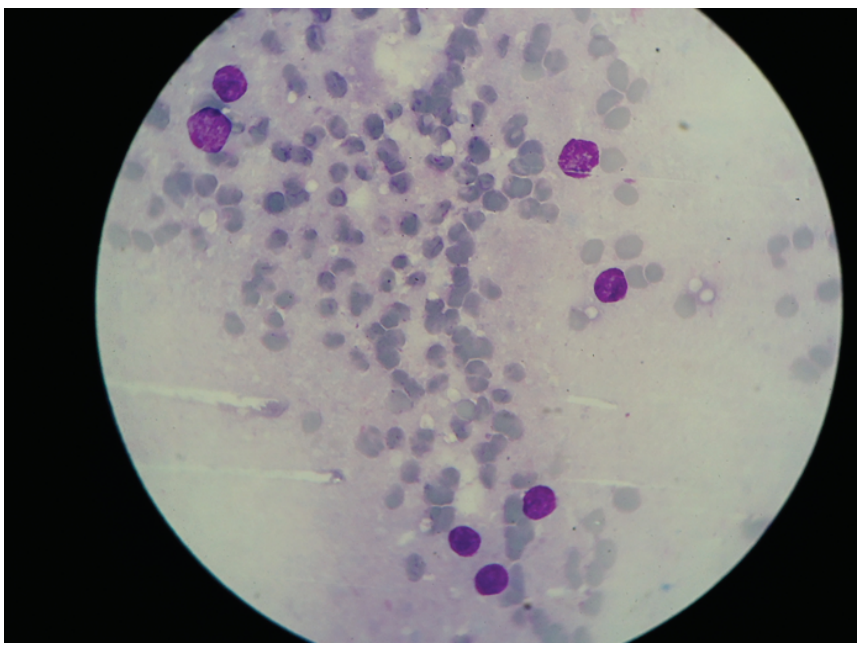

Figure 2. Negative control, Giemsa staining (1000× magnification).

\section{Discussion}

The clinical manifestations of weight loss, hepatosplenomegaly and ascites in the inoculated animals are also seen in human and canine cases of VL, in addition to other signs and symptoms that define the broad clinical spectrum of the disease and the confirmation of the parasitic infection (OLIVEIRA et al., 2004; CALDAS et al., 2006).

The frequency and richness of parasites found in the liver and spleen of the animals studied confirm the observations of other authors in experimental infection studies (MELENEY, 1925; GUTIERREZ et al., 1984; MELBY et al., 2001; SOUZA et al., 2001; RIÇA-CAPELA et al., 2003; WYLLIE; FAIRLAMB, 2006), and in canine and human cases of VL undergoing necropsy (MELENEY, 1925; PRAKASH et al., 2006).

A histopathological study in Cricetulus griseus hamsters experimentally infected with Leishmania donovani has showed that from day 9 post-inoculation parasitized cells in the spleen can be found. In the liver, the presence of Kupffer cells with small numbers of parasites can be seen at day 6 post-inoculation, raising the parasite load in relation to inoculation time (MELENEY, 1925).

The parasitism found in the kidneys $(33.3 \%)$ can be considered high compared to that reported in the literature, in view of the scarcity of reports about the parasite. Previous studies in humans, dogs and experimental models have not reported the parasite in the tissues here studied and have only described the histological changes induced in the kidneys DUARTE et al., 1983; OLIVEIRA et al., 1985; DUARTE; CORBETT, 1987; POLI, 1991; NIETO et al., 1992; SALGADO FILHO et al., 2003; PRIANTI et al., 2007; ALBUQUERQUE et al., 2008).

Carvalho et al. (2007) reported the absence of parasitic forms of Leishmania sp. in hamsters and the finding of antigenic fragments in phagocyte cells in the kidney glomerulus, tubular epithelial cells and interstice, suggesting that the parasite circulates through the kidneys, but it does not remain in the organ.

Background staining in immunohistochemistry in the of kidney slides may be explained by the same factors as described in the literature such as endogenous biotin, hydrophobic interactions, ionic and electrostatic interactions, endogenous peroxidase activity and use of unpurified antibodies (RAMOS-VARA, 2005).

The parasitism in the lungs (33.3\%) is less frequently reported in humans and dogs. In humans there are reports of a few infected cells and amastigotes in interstitial tissue, alveolar septa and bronchoalveolar lavage (MELENEY, 1925; ANDRADE, 1959; JOKIPII et al., 1992).

In naturally infected dogs, it has been reported the absence of parasites in the lungs or their presence in a small percentage of animals (DUARTE et al., 1986; GONÇALVES et al., 2003, SILVA et al., 2005).

In this study immunohistochemistry and organ impression techniques proved valuable for parasite examination and, when both were combined, they have yielded high positivity of lung tissue (33.3 to $44.4 \%)$.

The heart showed the lowest frequency of parasitic forms, which is consistent with other studies that have reported human cases with parasites seen in the lumen of small vessels and myocardium (MELENEY, 1925; RAMOS et al., 1994), and even the absence of amastigotes in this organ (RASO; SIQUEIRA, 1964).

The high percentage of animals with parasites in the CNS is a major finding. Although scarcely reported, it has been seen in other human and animal laboratories, in which amastigotes were seen in few meningeal cells and choroid plexus as well as in the brain (ABREU-SILVA et al., 2003; MELENEY, 1925; PRASAD; SEN, 1995). Silva et al. (2005) have identified Leishmania DNA in the cerebellum of dogs naturally infected with VL.

Prasad and Sen (1995) found parasites in the CSF of human patient with relapsing VL after splenectomy and parasitosis treatment and suggested that parasite migration could be explained by splenectomy.

In this study, the negative results in immunohistochemistry may be explained by the stage of disease as, in advanced cases parasites can be found in atypical organs such as the lungs (DUARTE et al., 1989), lumen of heart and CNS vessels (RAMOS et al., 1994). In the same way, in VL/ HIV association almost all organs that have phagocyte cells can be infected and atypical locations may 
occur as a consequence of parasite spread and low immunity (RAMOS et al. 1994; LAGUNA, 2003).

Although the negative results of immunomarking indicated absence of tissue amastigotes, parasitic forms were seen in the CNS through direct examination, which suggests that the parasites were not found in the tissues because they were circulating through the organ.

Ikeda et al. (2007) have argued that the absence of parasites in the CNS reported in naturally infected dogs may be due to non treatment of these animals. According to these authors, amastigotes would migrate to the CNS as a means of escaping from drug action in animals under treatment. Contrasting results were presented by Viñuelas et al. (2001) who found parasites within macrophages in the meninges of dogs with $\mathrm{VL}$ as well as extracellular amastigotes.

The present study permitted the visualization of circulating parasites which contrasts with Ikeda et al. (2007) assumption on the potential migration of parasites to escape from antileishmanial drug, since the animals studied did not receive any treatment.

Although neurological signs and symptoms have been described in humans and dogs infected with VL parasite, there is no consensus in the literature regarding the pathogenesis of VL in the CNS (CHUNGE et al., 1985; HASHIM et al., 1995; GARCIA-ALONSO et al., 1996; NOLI, 1999; IKEDA et al., 2007). Convulsions, dilated pupils, signs of cranial nerve palsy, facial ptosis, facial paralysis and ataxia are common neurological signs seen in canine VL (FEITOSA et al., 2000; IKEDA et al., 2007; OLIVEIRA et al., 2004; LIMA et al., 2003).

There are also reports in the medical literature of peripheral neuropathy associated with VL (MUSTAFA, 1965; CHUNGE et al., 1985). Hashim et al. (1995) found that patients gradually recover their health after specific treatment. Although the etiology of this picture has not been determined, the authors challenged the hypothesis of Fasanaro et al. (1991) that VL etiology would be a B-complex hypovitaminosis associated with the absorption of vitamin $B$ by the parasite or by the reduction of thiamine and pantothenic acid.

In addition to vascular congestion, coinfected patients have been reported with the presence of microglia cells with vacuolization without visualization of parasites. Amastigotes and particulate antigenic material have been evidenced by immunohistochemistry only inside the cells in lumen CNS vessels (RAMOS et al. 1994; LAGUNA, 2003).

\section{Conclusion}

Infected animals showed weight loss, hepatosplenomegaly and ascites, and leishmania amastigotes were seen in the spleen, liver, lungs, kidneys and heart. The results also allowed us to determine the circulation of parasitic forms in the CNS, serving as an alert to the professionals responsible for the management of VL patient as to neurological manifestation. Further studies are needed to clarify parasite effects in the CNS, contributing to the understanding of neurological pathogenesis of this major public health issue.

\section{Acknowledgements}

The research project was funded by the Fundaçáo de Apoio ao Desenvolvimento do Ensino, Ciência e Tecnologia of Mato Grosso do Sul (FUNDECT). The authors wish to thank the laboratory technicians for managing the animals and carrying out the techniques, and UFMS Animal House for providing the animals for the study.

\section{References}

ABREU-SILVA, A. L. et al. Central nervous system involvement in experimental infection with Leishmania (Leishmania) amazonensis. American Journal of Tropical Medicine and Hygiene, v. 68, n. 6, p. 661-665, 2003.

ALBUQUERQUE, B. C. N. C. et al. Alteraçóes estruturais em rins de caninos naturalmente infectados por Leishmania (Leishmania) chagasi. Revista Brasileira de Ciência Veterinária, v. 15, n. 1, p. 3-5, 2008.

ANDRADE, Z. A. Pneumonite intersticial no calazar. O Hospital, v. 55, n. 3, p. 371-381, 1959.

BRASIL. Ministério da Saúde. Secretaria de Vigilância em Saúde. Departamento de Vigilância Epidemiológica. Manual de vigilância e controle da leishmaniose visceral. Brasília: Ministério da Saúde, 2006. (Série A. Normas e Manuais Técnicos). Disponível em:<http://portal. saude.gov.br/portal/arquivos/pdf/manual_lv_grave_nc.pdf $>$. Acesso em: 19 abr. 2011.

CALDAS, A. J. M. et al. Are there differences in clinical and laboratory parameters between children and adults with American visceral leishmaniasis? Acta Tropica, v. 97, n. 3, p. 252-258, 2006. PMid:16420954. http://dx.doi.org/10.1016/j.actatropica.2005.09.010

CARVAlHO, A. A. et al. Caracterização histopatológica e imunoistoquímica da nefropatia da leishmaniose visceral experimental em hamster. Clínica Veterinária, n. 71, p. 60-64, 2007.

CHUNGE, C. N.; GACHIHI, G.; MUIGAI, R. Is neurological involvement possible in visceral leishmaniasis in Kenya? Transactions of the Royal Society of Tropical Medicine and Hygiene, v. 79, n. 6, p. 872, 1985. http://dx.doi.org/10.1016/0035-9203(85)90143-9

DUARTE, M. I. S.; CORBETT, C. E. P. Histopathological patterns of the liver involvement in visceral leishmaniasis. Revista do Instituto de Medicina Tropical de Sáo Paulo, v. 29, n. 3, p. 131-136, 1987. http://dx.doi.org/10.1590/S0036-46651987000300003

DUARTE, M. I. S. et al. Interstitial pneumonitis in canine visceral leishmaniasis. Revista do Instituto de Medicina Tropical de Sáo Paulo, v. 28 , n. 6, p. 431-436, 1986.

DUARTE, M. I. S. et al. Interstitial pneumonitis in human visceral leishmaniasis. Transactions of the Royal Society of Tropical Medicine and Hygiene, v. 83, n. 1, p. 73-76, 1989. http://dx.doi. org/10.1016/0035-9203(89)90712-8

DUARTE, M. I. S. et al. Interstitial nephritis in human kala-azar. Transactions of the Royal Society of Tropical Medicine and Hygiene, v. 77, n. 4, p. 531-537, 1983. http://dx.doi.org/10.1016/00359203(83)90131-1

FASANARO, A. M. et al. A Guillain-Barré syndrome as presenting manifestation of visceral leishmaniasis. The Lancet, v. 338, n. 8775, p. 1142, 1991. http://dx.doi.org/10.1016/0140-6736(91)91996-8 
FEITOSA, M. M. et al. Aspectos clínicos de cães com leishmaniose visceral no município de Araçatuba - São Paulo (Brasil). Clínica Veterinária, n. 28, p. 36-44, 2000.

FERROGLIO, E. et al. Characterization of Leishmania infantum strains in blood samples from infected dogs and humans by PCRRFLP. Transactions of the Royal Society of Tropical Medicine and Hygiene, v. 100, n. 7, p. 636-641, 2006. PMid:16343571. http://dx.doi. org/10.1016/j.trstmh.2005.09.008

GARCIA-ALONSO, M. et al. Presence of antibodies in the aqueous humour and cerebrospinal fluid during Leishmania infections in dogs. Pathological features at the central nervous system. Parasite Immunology, v. 18, n. 11, p. 539-546, 1996. PMid:9226692. http://dx.doi.org/10.1046/j.1365-3024.1996.d01-28.x

GONÇALVES, R. et al. Chronic interstitial pneumonitis in dogs naturally infected with Leishmania (Leishmania) chagasi: a histopathological and morphometric study. Revista do Instituto de Medicina Tropical de Sáo Paulo, v. 45, n. 3, p. 153-158, 2003.

GOTO, H.; LINDOSO, J. A. L. Immunity and immunosuppression in experimental visceral leishmaniasis. Brazilian Journal of Medical and Biological Research, v. 37, n. 4, p. 615-623, 2004. PMid:15064826. http://dx.doi.org/10.1590/S0100-879X2004000400020

GUTIERREZ, Y.; MAKSEM, J. A.; REINER, N. E. Pathologic changes in murine Leishmaniasis (Leishmania donovani) with special reference to the dynamics of granuloma formation in the liver. The American Journal of Patology, v. 114, n. 2, p. 222-230, 1984.

HASHIM, F. A. et al. Neurologic changes in visceral leishmaniasis. American Journal of Tropical Medicine and Hygiene, v. 52, n. 2, p. $149-154,1995$.

IKEDA, F. A. et al. Histological and immunohistochemical study of the central nervous system of dogs naturally infected by Leishmania (Leishmania) chagasi. Brazilian Journal of Veterinary Research and Animal Science, v. 44, n. 1, p. 5-11, 2007.

JOKIPII, L. et al. Leishmaniasis diagnosed from bronchoalveolar lavage. Scandinavian Journal of Infectious Diseases, v. 24, n. 5, p. 677-681, 1992. PMid:1465589. http://dx.doi.org/10.3109/00365549209054657

LACHAUD, L. et al. Comparison of six PCR methods using peripheral blood for detection of canine visceral leishmaniasis. Journal of Clinical Microbiology, v. 40, n. 1, p. 210-215, 2002. PMid:11773118. PMCid:120090. http://dx.doi.org/10.1128/JCM.40.1.210-215.2002

LAGUNA, F. Treatment of leishmaniasis in HIV-positive patients. Annals of Tropical Medicine and Parasitology, v. 97, suppl. 1, p. S135-S142, 2003. PMid:14678640. http://dx.doi. org/10.1179/000349803225002606

LIMA, V. M. F. et al. Anti-leishmania antibodies in cerebrospinal fluid from dogs with visceral leishmaniasis. Brazilian Journal of Medical and Biological Research, v. 36, n. 4, p. 485-489, 2003. PMid:12700826.

MATO GROSSO DO SUL (Estado). Secretaria de Estado de Saúde. Serviço de Vigilância Epidemiológica. Sistema de Informação de Agravos de Notificação - SINAN. Relatório de Notificações de LV. Leishmanioses. 2009. Disponível em: <http://www.saude.ms.gov.br/ index.php?templat $=$ list\&voltar $=$ home\&id_comp=634>. Acesso em: 26 fev. 2010.

MELENEY, H. E. The histopathology of kala-azar in the hamster, monkey, and man. American Journal of Pathology, v. 1, n. 2, p. 147-168, 1925. PMid:19969637. PMCid:1931682.
MELBY, P. C. et al. Leishmania donovani: Evolution and architecture of the splenic cellular immune response related to control of infection. Experimental Parasitology, v. 99, n. 1, p. 17-25, 2001. PMid:11708830. http://dx.doi.org/10.1006/expr.2001.4640

MELO, M. N. Leishmaniose visceral no Brasil: desafios e perspectivas. Revista Brasileira de Parasitologia Veterinária, v. 23, sup. 1, p. 41-45, 2004.

MUSTAFA, D. Neurological disturbances in visceral leishmaniasis. Journal of Tropical Medicine and Hygiene, v. 68, n.10, p.248-250, 1965. PMid:4284534.

NIETO, C. G. et al. Pathological changes in kidneys of dogs with natural Leishmania infection. Veterinary Parasitology, v. 45, n. 1-2, p. 33-47, 1992. http://dx.doi.org/10.1016/0304-4017(92)90025-5

NOLI, C. Canine leishmaniasis. Waltham Focus, v. 9, n. 2, p. 16-24, 1999.

OLIVEIRA, A. V. et al. Mesangial proliferative glomerulonephritis associated with progressive amyloid deposition in hamsters experimentally infected with Leishmania donovani. American Journal of Pathology, v. 120, n. 2, p. 256-262, 1985. PMid:4025511. PMCid:1887832.

OLIVEIRA, C. I. et al. Animal models for infectious diseases caused by parasites: leishmaniasis. Drug Discovery Today: Disease Models, v. 1, n. 1, p. 81-86, 2004. http://dx.doi.org/10.1016/j.ddmod.2004.07.005

PENNA, G. Doenças negligenciadas. Brasilia: Ministério da Saúde, 2008. Disponível em: <http://www.senado.gov.br/web/comissoes/cas/ ap/AP_20080604_Doencas_Negligenciadas.pdf>. Acesso em: 18 maio 2010 .

POLI, A. et al. Renal involvement in canine leishmaniasis: A lightmicroscopic, immunohistochemical and electron-microscopic study. Nephron, v. 57, n. 4, p. 444-452, 1991. PMid:2046828. http://dx.doi. org/10.1159/000186348

PRAKASH, A. et al. Visceral leishmaniasis masquerading as chronic liver disease. Journal of the Association of Physicians of India, v. 54, p. 893-894, 2006. PMid:17249262.

PRASAD, L. S. N.; SEN, S. Migration of Leishmania donovani amastigotes in cerebrospinal fluid. The Lancet, v. 346, n. 8968, p. 183-184, 1995. http://dx.doi.org/10.1016/S0140-6736(95)91242-8

PRIANTI, M. G. et al. Leishmania (Leishmania) chagasi - infected mice as a model for the study of glomerular lesions in visceral leishmaniasis. Brazilian Journal of Medical and Biological Research, v. 40, n. 6, p. 819-823, 2007. PMid:17581681. http://dx.doi.org/10.1590/S0100879X2007000600011

RAMOS, C. C. F.; DUARTE, M. I. S.; RAMOS, A. M. O. Leishmaniose visceral fatal associada à síndrome de imunodeficiência adquirida: relato de caso com achados necroscópicos e estudo imuno-histoquímico. Revista da Sociedade Brasileira de Medicina Tropical, v. 27, n. 4, p. 245-250, 1994. PMid:7855368.

RAMOS-VARA, J. A. Technical aspects of immunohistochemistry. Veterinary Pathology, v. 42, n. 4, p. 405-426, 2005. PMid:16006601. http://dx.doi.org/10.1354/vp.42-4-405

RASO, P.; SIQUEIRA, J. T. Subsídio ao conhecimento da anatomia patológica da leishmaniose visceral, com especial referência às lesóes pulmonares e cardíacas. O Hospital, v. 65, n. 6, p. 1291-1309, 1964.

RIÇA-CAPELA, M. J. et al. Immunological and histopathological studies in a rodent model infected with Leishmania infantum promastigotes or amastigotas. Parasitology Research, v. 89, n. 3, p. 163-169, 2003. 
SALGADO FILHO, N.; FERREIRA, T. M. A. F.; COSTA, J. M. L. Envolvimento da função renal em pacientes com leishmaniose visceral (calazar). Revista da Sociedade Brasileira de Medicina Tropical, v. 36, n. 2, p. 217-221, 2003. PMid:12806457. http://dx.doi.org/10.1590/ S0037-86822003000200004

SILVA, E. A. et al. Detection of Leishmania DNA in phlebotomines captured in Campo Grande, Mato Grosso do Sul, Brazil. Experimental Parasitology, v. 119 , n. 3, p. 343-348, July 2008. http://dx.doi. org/10.1016/j.exppara.2008.03.011

SILVA, A. V. M. et al. Leishmaniose em cães domésticos: aspectos epidemiológicos. Cadernos de Saúde Pública, v. 21, n. 1, p. 324-328, 2005. http://dx.doi.org/10.1590/S0102-311X2005000100036
SOUZA, E. P. et al. Occurrence of Leishmania donovani parasitemia in plasma of infected hamsters. Acta Tropica, v. 80, n. 1, p. 69-75, 2001. http://dx.doi.org/10.1016/S0001-706X(01)00150-4

VIÑUELAS, J. et al. Meningeal leishmaniosis induced by Leishmania infantum in naturally infected dogs. Veterinary Parasitology, v. 101, n. 1, p. 23-27, 2001.

WYLLIE, S.; FAIRLAMB, A. H. Refinement of techniques for the propagation of Leishmania donovani in hamsters. Acta Tropica, v. 97, n. 3, p. 364-369, 2006. PMid:16464432. http://dx.doi.org/10.1016/j. actatropica.2006.01.004 